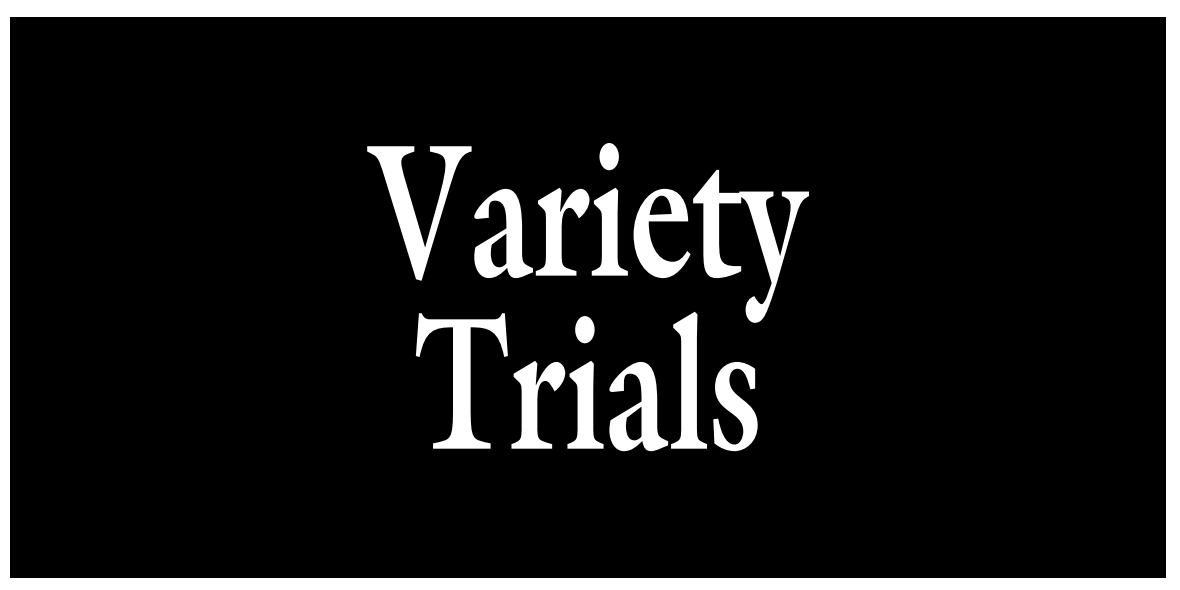

\section{Pennsylvania Statewide Synergistic Sweet Corn Cultivar Evaluation}

\author{
Thomas M. Butzler ${ }^{1,8}$, Elsa S. Sánchez ${ }^{2}$, Steven M. Bogash ${ }^{3}$, \\ Timothy E. Elkner ${ }^{4}$, William J. Lamont, Jr ${ }^{5}$, Robert Pollock ${ }^{6}$, \\ and Lee J. Stivers ${ }^{7}$
}

AdDitional Index wORDs. Zea mays, ear length, ear diameter, ear size, ear height, variety trial, picking ease

\begin{abstract}
SUMMARY. To provide growers with regional and statewide recommendations, 23 cultivars of bicolor and white synergistic sweet corn (Zea mays) were evaluated in southwestern, central, and southeastern Pennsylvania. 'Temptation' was the standard. Despite differing production practices used in all locations, all cultivars were not different or produced more marketable primary ears compared with Temptation. Paydirt was the only cultivar to produce lower marketable yields by weight than Temptation in 2 site years or more. However, 'Paydirt' has an early maturity, which improves its acceptability. Very few ears were unmarketable. In terms of ear size, measured as diameter and length, overall all cultivars were not different from Temptation. 'Temptation' is early maturing and ear size was expected to be smaller than later maturing cultivars. This was not observed. Ease of hand harvesting was determined by measuring two factors: distance from the base of the primary ear to the soil line and ease of picking ( $1-5$ rating scale where $1=$ difficult and 5 = easy). The closer the primary ear was to the soil line was thought to be more difficult to harvest. 'Synergy', 'Espresso', 'Kristine', and 'Paydirt' ears were lower than 'Temptation' on the culm in 2 site years or more. 'Whiteout', 'Synergy', and 'Mattapoisett' were rated as more difficult to pick than 'Temptation' in 2 site years or more. Distance from the soil line to the primary ear and picking ease ratings were not observed to be closely related to each other and a combination of these and other factors may more accurately reflect the ease of hand harvesting. Overall, growers in our region have access to a lot of synergistic sweet corn cultivars with acceptable yield, quality, and ease of hand harvesting characteristics giving them a wide range of options.
\end{abstract}

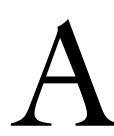
s of 2012, Pennsylvania was ranked 10 th in the United State for fresh market sweet corn production. Forty-eight percent (1898 farms) of Pennsylvania growers produce sweet corn on 12,715 acres [U.S. Department of Agriculture (USDA), 2014]. Growers at the 2011 Mid-Atlantic Fruit and Vegetable Convention, an annual grower meeting of about 2200 fruit and vegetable growers and industry representatives, ranked sweet corn second among vegetable crops warranting research efforts to maintain profitability (Sánchez et al., 2012). Additionally, the Pennsylvania Vegetable Growers Association, representing the interests of Pennsylvania growers, funded this project.

In Pennsylvania, bicolor sweet corn cultivars predominate production; however, areas exist where white cultivars dominate including in the southeastern part of the state. Conversations with seed company representatives indicate that the seed industry is moving toward more synergistic offerings. Compared with $s u$, $s e$, and $s h_{2}$ cultivars, synergistic cultivars are generally thought to have the best flavor, texture, and aroma; and have high sugar content. Past sweet corn cultivar evaluations have focused on different genetics (Kleinhenz, 2003; Simmone et al., 1999).

When selecting cultivars, ear quality is as important as marketable yield for profitability. Consumers are first attracted ear appearance, while taste can result in repeat purchases. In most U.S. markets, consumers prefer an 8- to 9-inch ear with a dark green husk, long and dark green flag leaf, and 16 straight rows of small deep and sweet kernels filled to the tip of the ear (Tracy, 2001). In addition to yield and ear quality, the ease or difficulty in hand harvesting may be another consideration when selecting cultivars. While many growers harvest mechanically in Pennsylvania, many also harvest by hand.

The objective of this research was to evaluate bicolor and white synergistic sweet corn cultivars to develop recommendations for fresh, direct market growers in Pennsylvania and the mid-Atlantic region.

\section{Materials and methods}

Twenty-three cultivars of bicolor and white synergistic sweet corn (Table 1 ) were grown in a conventional system in four locations across the state in 2012-13. 'Temptation' was

\begin{tabular}{llll}
\hline $\begin{array}{l}\text { Units } \\
\text { To convert U.S. to SI, } \\
\text { multiply by }\end{array}$ & U.S. unit & SI unit & $\begin{array}{l}\text { To convert SI to U.S., } \\
\text { multiply by }\end{array}$ \\
\hline 0.4047 & acre(s) & $\mathrm{ha}$ & 2.4711 \\
102.7902 & acre-inch(es) & $\mathrm{m}^{3}$ & 0.0097 \\
0.3048 & $\mathrm{ft}$ & $\mathrm{m}$ & 3.2808 \\
2.54 & inch(es) & $\mathrm{cm}$ & 0.3937 \\
0.4536 & $\mathrm{lb}$ & $\mathrm{kg}$ & 2.2046 \\
1.1209 & $\mathrm{lb} / \mathrm{acre}$ & $\mathrm{kg} \cdot \mathrm{ha}^{-1}$ & 0.8922
\end{tabular}


used as a standard. It is a longstanding cultivar and the only one in this evaluation that has been recommended in the Commercial Vegetable Production Recommendations guide for the mid-Atlantic region since 2001 (Orzolek et al., 2001). Evaluations were located in southwestern Pennsylvania at growers' farms in Venetia [2012, Bebout Farms (lat. 40 16'11.97'N, long. $\left.\left.\quad 80^{\circ} 03^{\prime} 20.95^{\prime} \mathrm{W}\right)\right], \quad$ and Jeannette [2013, Schramm Farms (lat. $\quad 40^{\circ} 22^{\prime} 32.80^{\prime} \mathrm{N}, \quad$ long. 79³8'20.70' W) ], in central Pennsylvania at the Horticulture Research Farm, Russell E. Larson Research and Education Center, Rock Springs (lat. $40^{\circ} 42^{\prime} 45.04$ 'N, long 77 $57^{\prime} 12.44^{\prime \prime}(\mathrm{W})$, and in southeastern Pennsylvania at the Penn State Southeast Agricultural Research and Extension Center, Manheim (lat. $40^{\circ} 07^{\prime} 05.11$ 'N, long. $76^{\circ} 25^{\prime} 45.69^{\prime \prime} \mathrm{W}$ ) (Fig. 1). These three locations represent the major agricultural centers of Pennsylvania's seven physiographic provinces.

Cultivars were arranged in a randomized complete block design with four replications and three 8.3- to 12.5 - $\mathrm{ft}$ rows of 15 plants per plot. Data were collected from the middle row. Pests were managed, depending on levels, in accordance with recommendations for commercial production of sweet corn (Orzolek et al., 2012).

Use of trade names does not imply endorsement of the products named or criticism of similar ones not named.

The authors wish to acknowledge the Pennsylvania Vegetable Research and Marketing Board for funding this project. We would also like to thank our on-farm collaborators at Bebout Farms and Schramm Farms as well as Rupp Seeds Inc., Seedway LLC, Seminis Vegetable Seeds, Inc., Harris Moran Seed Co., Siegers Seed Co., and Crookham Co., for their generous donation of seeds used in this study. We also would like to thank our families for their support.

${ }^{1}$ Senior Extension Educator, Penn State Extension, 47 Cooperation Lane, Mill Hall, PA 17751

${ }^{2}$ Associate Professor, Department of Plant Science, The Pennsylvania State University, University Park, PA 16802

${ }^{3}$ Associate Extension Educator, Penn State Extension, 181 Franklin Farms Lane, Chambersburg, PA 17202

${ }^{4}$ Senior Extension Educator, Penn State Extension, 1383 Arcadia Road, Room 140, Lancaster, PA 17601

${ }^{5}$ Professor, Department of Plant Science, The Pennsylvania State University, University Park, PA 16802

${ }^{6}$ Extension Educator, Penn State Extension, 827 Water Street, Indiana, PA 15701

${ }^{7}$ Senior Extension Educator, Penn State Extension, 100 West Beau Street, Suite 601, Washington, PA 15301

${ }^{8}$ Corresponding author. E-mail: tmb124@psu.edu.

Table 1. Cultivars and seed sources of sweet corn evaluated in central, southeastern, and southwestern Pennsylvania in 2012-13. The standard was 'Temptation'.

\begin{tabular}{|c|c|c|c|}
\hline Cultivar & $\begin{array}{c}\operatorname{Yr}(s) \\
\text { evaluated }\end{array}$ & $\begin{array}{l}\text { Reported time } \\
\text { to maturity }(d)^{z}\end{array}$ & Seed source \\
\hline \multicolumn{4}{|l|}{ Bicolor } \\
\hline Allure & $2012-13$ & 75 & Rupp Seeds, Wauseon, OH \\
\hline Cuppa Joe & $2012-13$ & 73 & \\
\hline Espresso & $2012-13$ & 72 & \\
\hline BC 0805 & $2012-13$ & 82 & SeedWay, Elizabethtown, PA \\
\hline Ka-Ching & $2012-13$ & 78 & \\
\hline Primus & $2012-13$ & 81 & \\
\hline Paydirt & $2012-13$ & 70 & \\
\hline Profit & $2012-13$ & $70-72$ & \\
\hline Providence & $2012-13$ & 80 & \\
\hline BC 1102 & $2012-13$ & 73 & Seminis Vegetable Seeds, \\
\hline Temptation II & $2012-13$ & 72 & Oxnard, CA \\
\hline Synergy & $2012-13$ & 76 & Seigers Seed Co., Holland, MI \\
\hline Temptation I & $2012-13$ & 72 & \\
\hline Jackie & $2012-13$ & 70 & Harris Moran Seed Co., \\
\hline Montauk & $2012-13$ & 79 & Modesto, CA \\
\hline Kristine & $2012-13$ & 77 & $\begin{array}{l}\text { Seigers Seed Co./Crookham Seed } \\
\text { Co., Holland, MI/Caldwell, ID }\end{array}$ \\
\hline \multicolumn{4}{|r|}{ 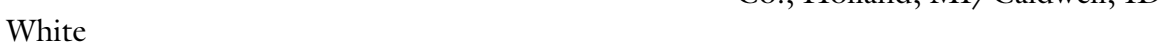 } \\
\hline Avalon & $2012-13$ & 84 & SeedWay \\
\hline Mattapoisett & $2012-13$ & 80 & \\
\hline Whiteout & $2012-13$ & 73 & \\
\hline Captivate & $2012-13$ & 88 & Rupp Seeds \\
\hline Illusion & $2012-13$ & 72 & \\
\hline Edelweiss & $2012-13$ & 76 & Harris Moran Seed Co. \\
\hline Silver Duchess & $2012-13$ & 78 & Seigers Seed Co. \\
\hline
\end{tabular}

${ }^{\mathrm{z}}$ As listed in seed catalogs.

At the southwestern locations, cultivars were direct seeded with a push seeder (1001-B Precision Garden Seeder; Earthway, Bristol, IN) on 6 June in 2012 and 21 May 2013 with 8 - to 10 -inch in-row spacing and 38 -inch row spacing creating a stand of 16,000 to 20,000 plants/acre. Fertility protocols were based on the grower cooperator standard practices. In 2012, $144.5 \mathrm{lb}$ nitrogen $(\mathrm{N}), 117$ $\mathrm{lb}$ phosphorus $(\mathrm{P})$, and $87 \mathrm{lb}$ potassium $(\mathrm{K})$ per acre were applied as follows: $57 \mathrm{lb} \mathrm{N}, 57 \mathrm{lb} \mathrm{P}$, and $57 \mathrm{lb} \mathrm{K}$ per acre were broadcast preplant, 30 $\mathrm{lb} \mathrm{N}, 60 \mathrm{lb} \mathrm{P}$, and $30 \mathrm{lb} \mathrm{K}$ per acre were banded at planting and 57.5 $\mathrm{lb} /$ acre $\mathrm{N}$ was sidedressed. In 2013 , $38 \mathrm{lb} \mathrm{N}, 16.4 \mathrm{lb} \mathrm{P}$, and $31.6 \mathrm{lb} \mathrm{K}$ were applied per acre. Weeds were managed with preemergent herbicides: atrazine at $\mathrm{l} \mathrm{lb} /$ acre (AAtrex 4L; Syngenta Crop Protection, Wilmington, DE) and $2.86 \mathrm{lb} /$ acre of metolachlor (Dual II Magnum, Syngenta Crop Protection). Insects were managed with four applications of methomyl $0.9 \mathrm{lb} /$ acre
(Lannate LV; DuPont Crop Protection, Wilmington, DE) plus lambdacyhalothrin at $0.21 \mathrm{lb} /$ acre (Warrior II, Syngenta Crop Protection). Overhead irrigation was used during plant establishment only. The soil type at Bebout Farm was a DormontCulleoka complex and the soil type at Schramm Farms was a Dormont silt loam.

At the central site, cultivars were hand seeded on 1 June in 2012 and 2013 with 8 - to 10 -inch in-row spacing and 30 -inch between row spacing for a population of 20,000 to 26,000 plants/acre. In 2012, $50 \mathrm{lb} /$ acre $\mathrm{N}$ and $20 \mathrm{lb} /$ acre $\mathrm{P}$ were broadcast preplant. Based on soil test results, K was not added. In 2013, $50 \mathrm{lb} /$ acre $\mathrm{N}$ was broadcast preplant. Weeds were managed with a preplant application of mesotrione at $0.08 \mathrm{lb} /$ acre (Callisto, Syngenta Crop Protection) and atrazine and metolachlor at $0.58 \mathrm{lb} /$ acre and $0.45 \mathrm{lb} /$ acre, respectively (Bicep II Magnum, Syngenta Crop Protection). Insect pests and diseases were left unmanaged. Supplemental water was provided through a drip 


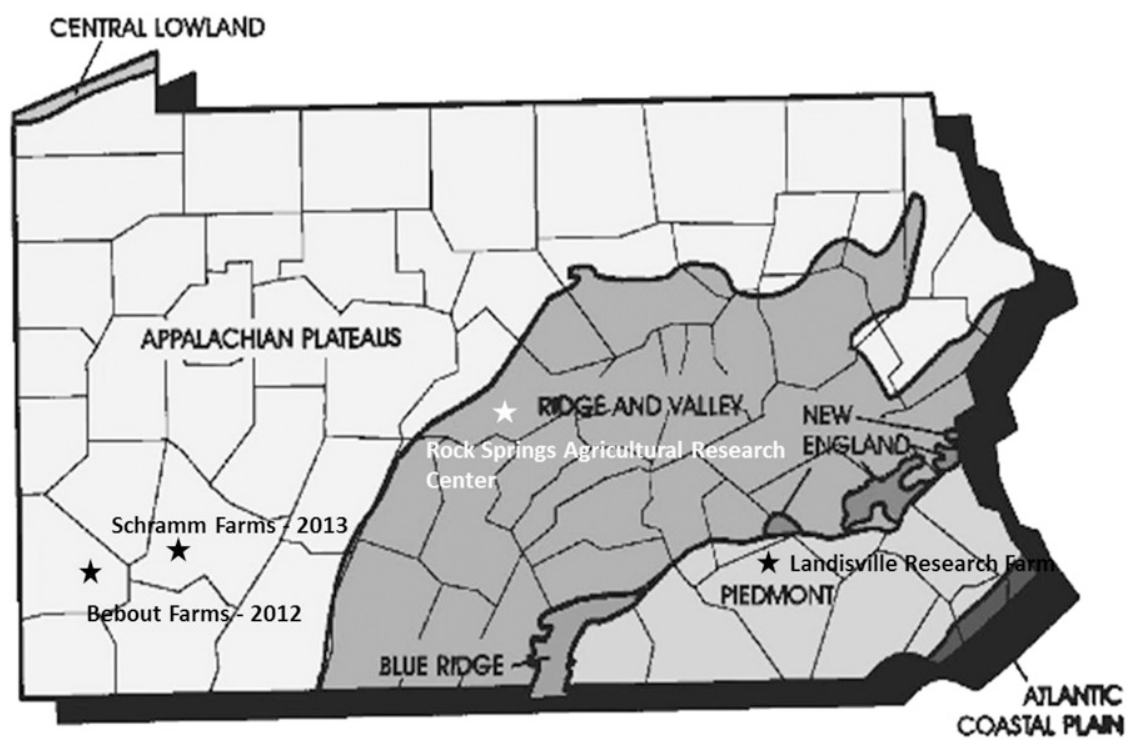

Fig. 1. Site of the four sweet corn cultivar evaluation sites in Pennsylvania's seven physiographic regions (defined by its geology and its landforms).

irrigation (T-Tape model 508-12450; John Deere, Moline, IL) system to reach 1 to 1.5 acre-inch water per week. The soil type was a Hagerstown silt loam.

At the southeastern site, cultivars were direct seeded with a plot planter (Cone Plot Planter; Almaco, Neveda, IA) on 21 May 2012 and 30 May 2013 with 8 - tol0-inch inrow spacing and 38 -inches between rows for a population of 16,000 to 20,000 plants/acre. In 2012, $150 \mathrm{lb}$ $\mathrm{N}, 50 \mathrm{lb} \mathrm{P}$, and $50 \mathrm{lb}$ K per acre were broadcast preplant and incorporated. In $2013,100 \mathrm{lb} \mathrm{N}, 160 \mathrm{lb} \mathrm{P}$, and $160 \mathrm{lb} \mathrm{K}$ per acre were applied preplant and incorporated. Weeds were managed in both years with preplant applications of $2 \mathrm{lb} /$ acre of glyphosate (Credit 41; Nufarm, Burr Ridge, IL), $1.15 \mathrm{lb} /$ acre of metolachlor (Dual II Magnum), and $\mathrm{l} \mathrm{lb} /$ acre of atrazine (Makhteshim Agan of North America, Raleigh, NC). Insects were controlled with weekly applications of $0.02 \mathrm{lb} /$ acre lambda-cyhalothrin (Warrior, Syngenta Crop Protection) starting at silking in both years. Supplemental water was provided through drip irrigation system to reach 1 to 1.5 acre-inch water per week. The soil type was a Hagerstown silt loam.

To help determine the ease of hand harvesting, distance from the soil line to the base of the primary ear from the middle 10 plants in a plot was recorded. Ears from 10 (southwestern site 2013 only) to 15 plants were harvested when all plants of an individual cultivar reached maturity. Since the effort required to hand pull an ear from a culm can vary by cultivar, ears were also rated for ease or difficulty in hand harvest (picking ease) using a five-point scale where $\mathrm{l}=$ difficult and $5=$ easy. For uniformity, a single individual at each site was tasked with determining picking ease for both years of the study. Ears were categorized as marketable or unmarketable, counted and weighed. Visible insect damage resulted in an ear being unmarketable. Ear size (diameter and length) was measured from 10 ears per plot.

All data were analyzed using the GLIMMIX procedure in SAS (version 9.2; SAS Institute, Cary, NC). When probability values were less than or equal to 0.05 , means were separated using Tukey's multiple comparison test. Data were pooled for all sites and years. Interactions among cultivar, site, and year were significant for all analyses.

\section{Results and discussion}

MARKETABLE AND UNMARKETABLE YIELDS. The number of marketable ears produced by all cultivars, in the 6 site years, was not different from Temptation except for Paydirt in 2012 and BC 1102 in 2013 at the central site, which produced fewer ears (Table 2).
By weight, 'Avalon' produced higher marketable yields than 'Temptation' and 'Paydirt' lower at the southwestern site in 2012. In 2013, all cultivars were not different in marketable weight than Temptation except for Profit which had higher weights and Cuppa Joe with lower weights.

'Jackie' and 'Paydirt' had lower marketable yields by weight in 2012 at the central site compared with 'Temptation' while 'Montauk' was higher. In 2013, the cultivars Allure, BC 1102, Illusion, Paydirt, Profit, and Whiteout had lower yields by weight than Temptation. All other cultivars were not different from Temptation.

All cultivars, in both years at the southeastern site, were not different from Temptation based on marketable weight except for Montauk, which yielded higher in 2012 .

The number of unmarketable ears for all cultivars, in the 6 site years, was not different from Temptation except for Paydirt in 2012 and Cuppa Joe in 2013 at the southwestern site which produced more unmarketable ears (Table 3 ).

'Paydirt' produced higher unmarketable yield by weight $(3.54 \mathrm{lb})$ than 'Temptation' $(0.15 \mathrm{lb})$ which was not different from any other cultivar in the southwestern site in 2012. In 2013, 'Temptation' was not different from 'Allure', BC 1102', 'Cuppa Joe', Edelweiss', 'Illusion', and 'Paydirt'. All other cultvars produced lower unmarketable yields than 'Temptation'. Unmarketable yields by weight were not different from 'Temptation' for any cultivar in both years in the central and southeastern sites.

Most ears produced by 'Temptation' were marketable ( 13.13 to 15 over the 6 site years); as were those produced by the other cultivars evaluated. The number of ears produced per plot by 'Temptation' was not different between site and year (data not shown). Four locations (two in southwestern, one in central, and one in southeastern Pennsylvania) were used in this study and production practices varied by location including irrigation, fertility, and spacing. However, when following pest management recommendations (Orzolek et al., 2012), growers can expect most ears to be marketable independent of 


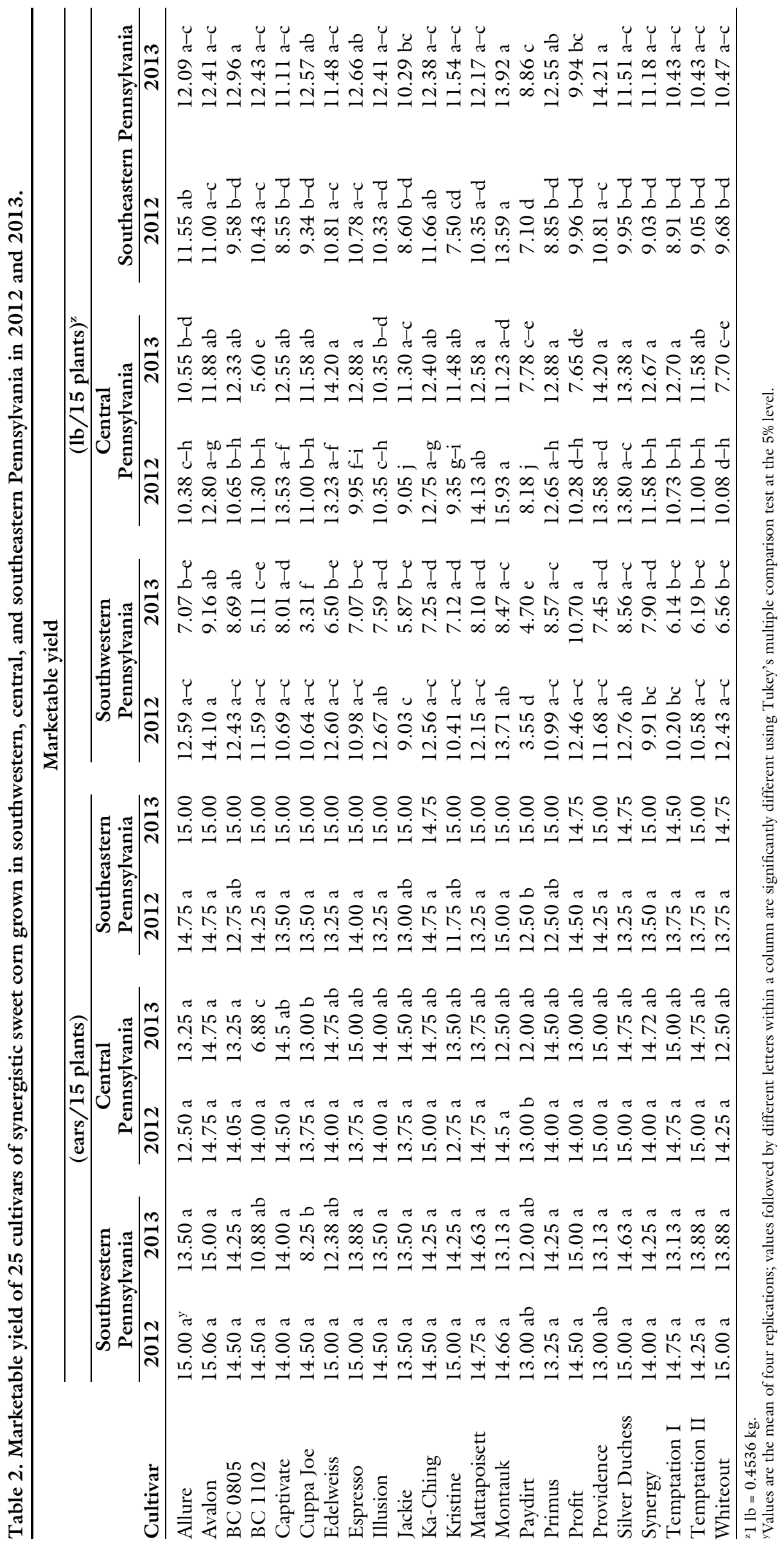




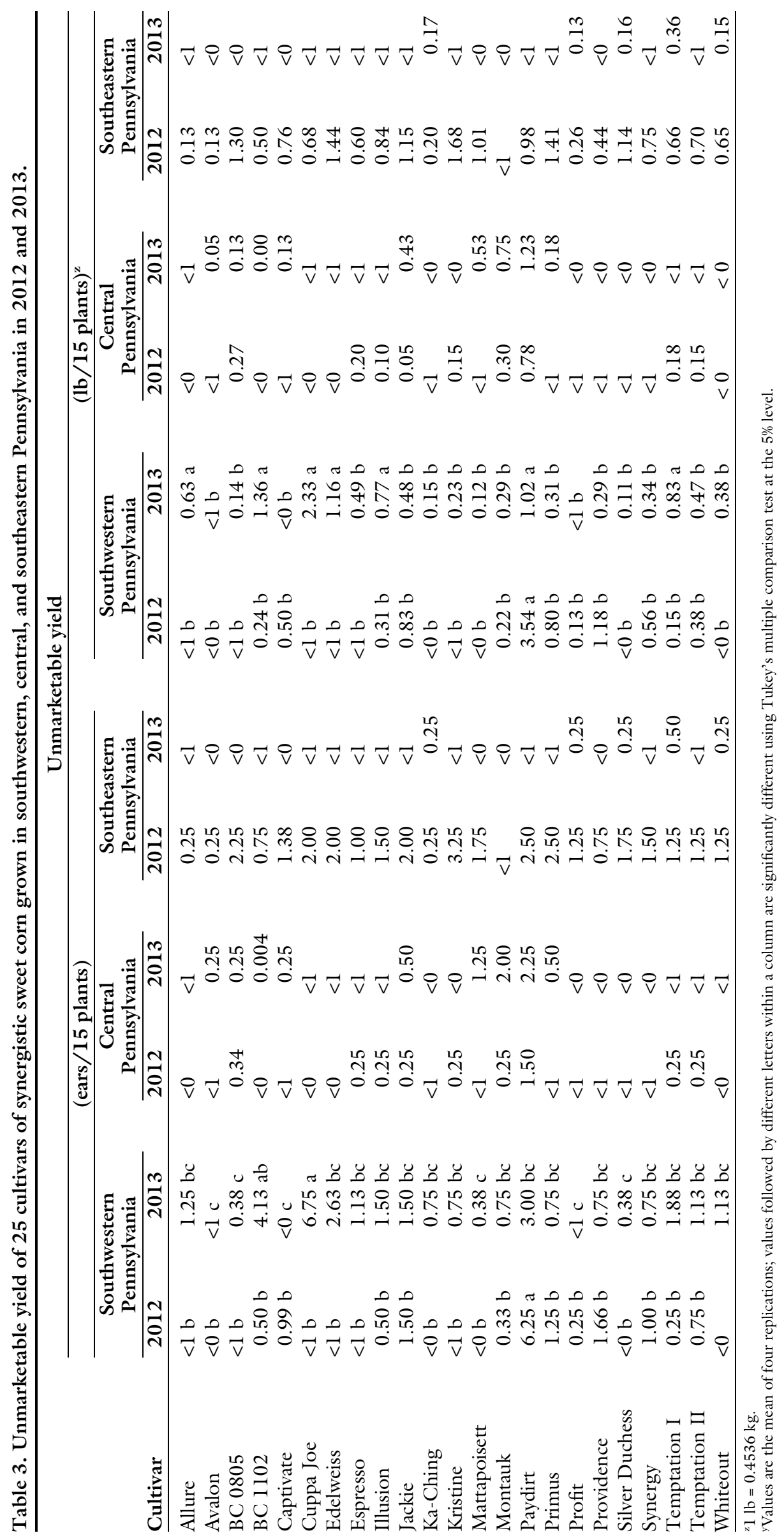


location and production practices. Based on the number of marketable primary ears, all cultivars are recommended.

By weight, marketable yield per plot from 'Temptation' was between 6.14 and $12.7 \mathrm{lb}$ over the 6 site years. Generally, marketable weight was not different between site and year. However, in 2013, marketable ear weight per plot was lower at the southwestern site compared with the central and southeastern sites (data not shown). The use of irrigation only during establishment combined with the production practices and geographic location may account for this result. A cultivar needed to perform equally or superior to 'Temptation' in a minimum of 4 site years to be recommended. With the exception of 'Paydirt', all cultivars produced equal or higher marketable yield by weight to Temptation in at least 4 site years of the evaluation. 'Paydirt' marketable weight per plot was lower at the southwestern site compared with the central site in 2012 and compared with the southeastern site in 2013 (data not shown). Otherwise, differences between site and year were not observed for this cultivar. While Paydirt produced ears weighing less than Temptation in 3 site years, it is a common cultivar currently grown in Pennsylvania. It has gained favor because it matures early [70 d (Table 1$)]$ and has excellent flavor. Overall, growers in our region have access to a lot of synergistic sweet corn cultivars with acceptable marketable yields giving them a wide range of options.

EAR SIZE. Ear diameter of 'Temptation' was not different from most other cultivars in the 6 site years (Table 4). However, 'Edelweiss' had a larger ear diameter in 2012 in southeastern Pennsylvania and 'BC 1102' had a smaller ear diameter in 2013 at the central site.

Ear length of most cultivars was not different from Temptation in the 6 site years; however, Avalon in 2012 in central Pennsylvania and Allure in 2013 in southwestern Pennsylvania produced longer ears. Only 'BC 1102 ' in 2013 at the central Pennsylvania site produced smaller ears than 'Temptation' during the 2 -year trial.

Overall ear size for all cultivars was comparable to Temptation. The average ear diameter for 'Temptation' was between 1.64 and 1.86 inches with no differences between site and year (data not shown). Ear length for 'Temptation' ranged from 6.69 to 7.46 inches also with no differences between site and year. Temptation is an early maturing cultivar [72 d (Table 1)]. For size, it demonstrated phenotypic stability between year and location. It was expected that ear maturity would relate to ear size, with earlier maturing cultivars, such as Temptation, producing smaller ears than later ones. However, this was not observed. Ear length values were lower than the 8- to 9-inch ear length that is preferred by consumers in U.S. markets (Tracy, 2001). Temptation is a longstanding cultivar in the mid-Atlantic region which suggests that consumer acceptance in this region may vary from this standard. Additionally, numerous traits are considered when choosing sweet corn and others may be weighed more heavily than ear length.

EASE OR DIFFICULTY OF HAND HARVESTING. In both years at the southwestern site, 'Espresso', Kristine', and 'Paydirt' had ears lower on the culm than 'Temptation' (Table 5 ). 'Synergy' was only lower in 2013. All other cultivars at the southwestern sites were not different from Temptation in both years.

In central Pennsylvania, there were no differences in 2012. However, in 2013, 'BC1102', 'Espresso', Kristine', 'Profit', and 'Synergy' had ears lower on the culm than 'Temptation'. All other cultivars were not different from Temptation.

'Captivate' and 'Mattapoisett' had ears located higher and 'Paydirt' lower on the culm than 'Temptation' in 2012 and 2013 at the southeastern site. 'Whiteout' was located higher on the culm only in 2012 while 'Kristine' was lower only in 2013 in the southeast. All other cultivars were not different from Temptation.

In southwestern Pennsylvania, 'BC1102', 'Kristine', 'Synergy', and 'Whiteout' were rated more difficult to pick than 'Temptation' in 2012. Only the cultivars Captivate and Mattapoisett were more difficult to pick than Temptation in 2013. All other cultivars were not different from Temptation.

In 2012 and 2013, 'Whiteout' was more difficult to pick than 'Temptation' in central Pennsylvania. 'Synergy' only rated lower than 'Temptation' in 2013. All other cultivars were not different from 'Temptation'.

At the southeastern site, there were no differences between cultivars for picking ease rating in 2012; however, Cuppa Joe, Jackie, Mattapoisett, Montauk, Primus, and Synergy rated lower than Temptation in 2013.

The closer the primary ear was to the soil line required more bending and therefore was considered more difficult to hand harvest. 'Temptation' over the 6 site years, ranged from 13.37 to 24.48 inches from soil line to the base of the primary ear. In 2012, ear height for 'Temptation' was higher at the southwestern site compared with the other sites, which were not different from each other. In 2013, ear height was not different between site and year.

'Synergy', 'Espresso', 'Kristine', and 'Paydirt' ears were lower than 'Temptation' on the culm in 2 site years or more. Ear height for 'Kristine' and 'Paydirt' did not differ between sites or years (data not shown). 'Espresso' ears were higher on the culm in the southeastern site compared with the central site in 2013 . Otherwise, ear height for this cultivar did not differ between site and year. 'Synergy' ears were lower on the culm at the central site compared with the southwestern and southeastern sites in 2013. Otherwise, ear height for this cultivar did not differ between site and year.

'Temptation' was rated between 3.4 and 4.9 over the 6 site years indicating it was generally easy to hand harvest. Picking ease did not differ between site and year for 'Temptation' (data not shown).

'Whiteout', 'Synergy', and 'Mattapoisett' were rated as more difficult to pick than 'Temptation' in 2 site years or more. 'Whiteout' picking ease ratings did not vary between site and year. 'Synergy' ratings were higher at the southeastern site compared with the southwestern site in 2012. For 'Mattapoisett' ratings were higher in the southeastern site compared with the southwestern site in 2012 and higher in the central site compared with the southwestern and southeastern site in 2013. Otherwise, ratings did not differ between site and year for 'Synergy' or 'Mattapoisett'.

Overall, the qualitative ease of harvest ratings were not observed to 


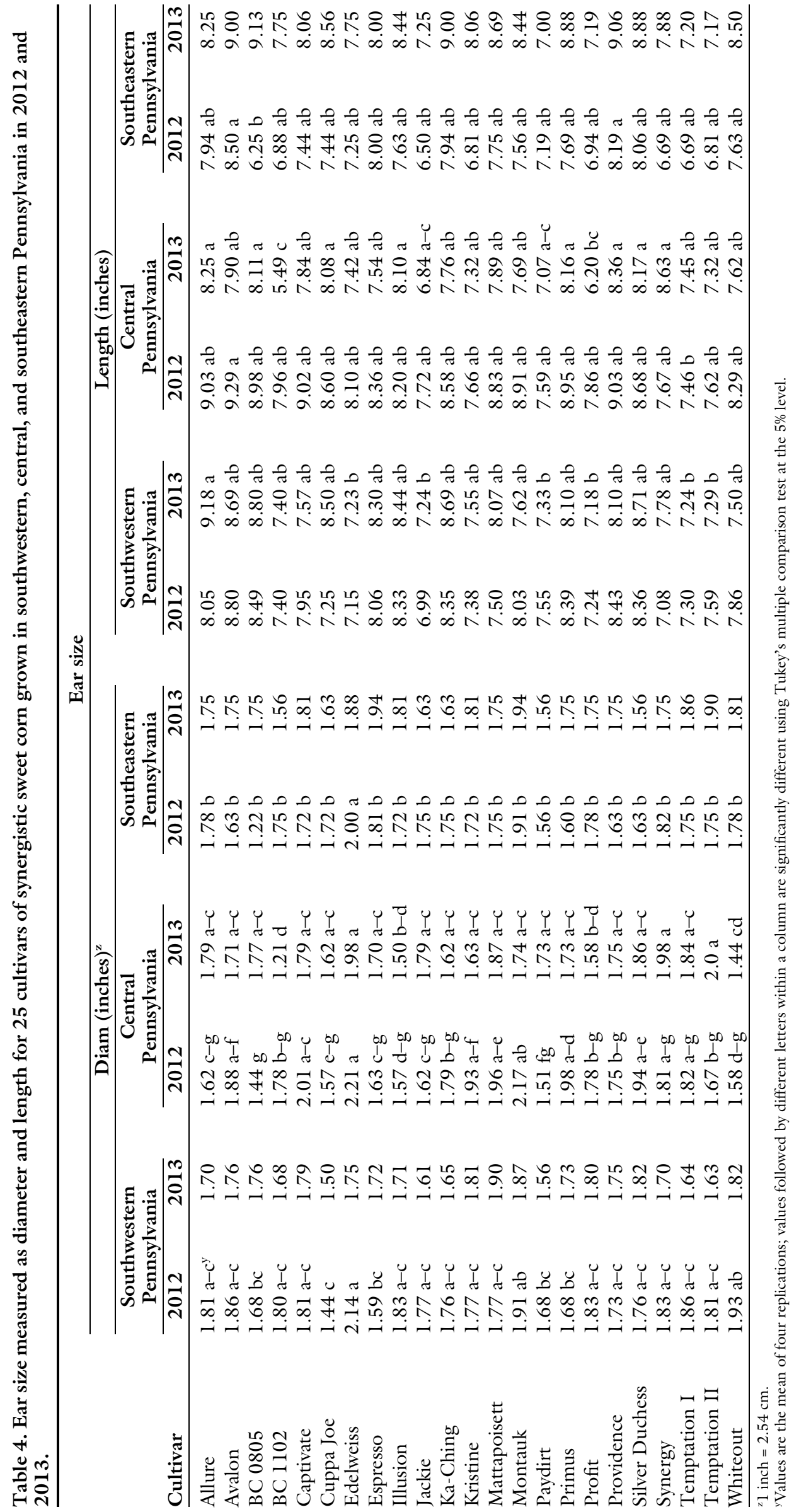




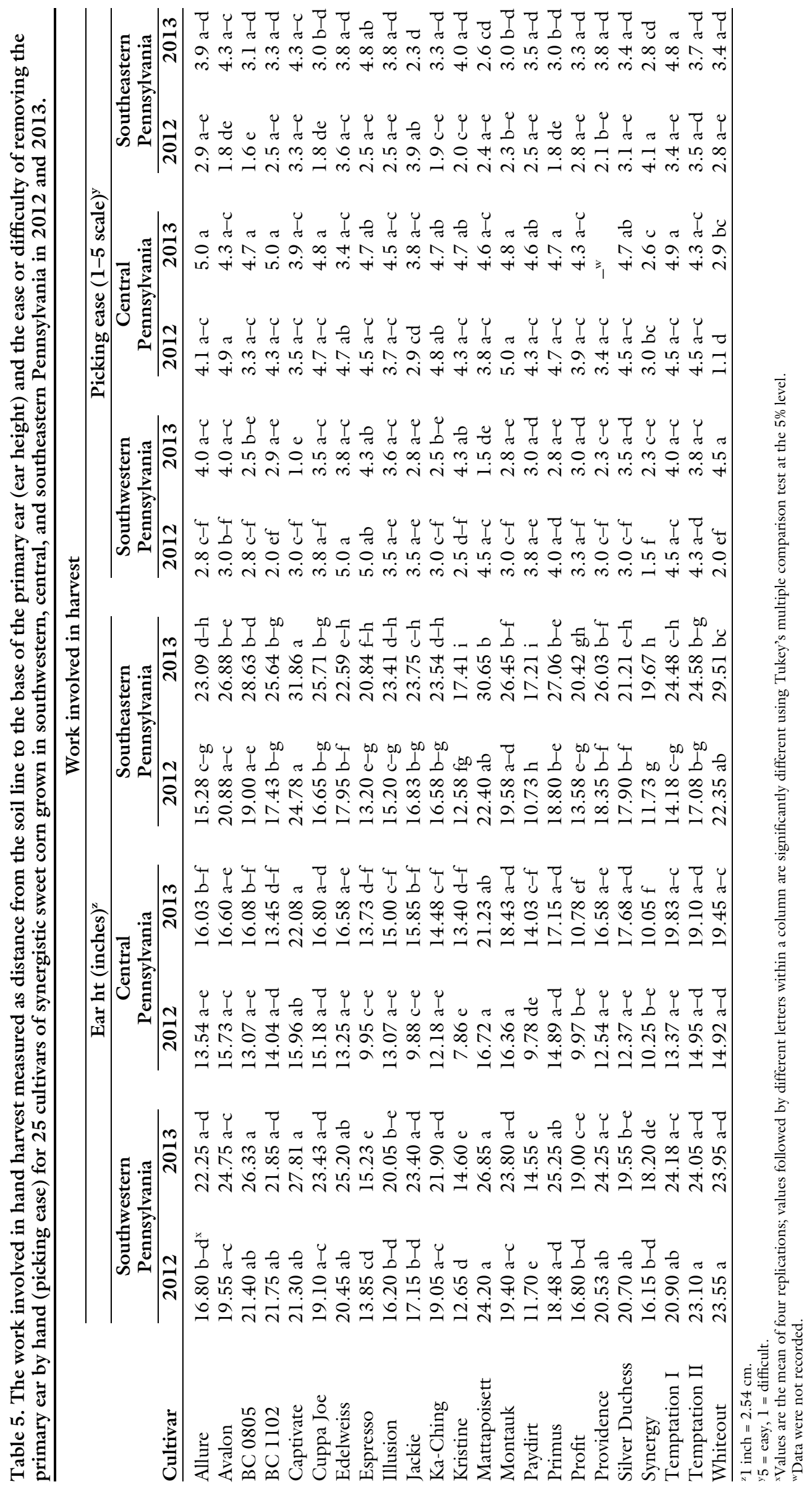


relate to the quantitative ear height measurements in this study indicating that the effort required to harvest an ear and its distance from the soil line are independent characteristics and both affect picking ease. Measurements also varied, depending on cultivar, between location and year (data not shown). A combination of the two traits may be a better representation of picking ease. 'Synergy' and 'Mattapoisett' ears were lower on the culm and rated as more difficult to pick than 'Temptation' in 2 site years or more suggesting that other cultivars may be more suitable for hand harvest. Shank length has also been observed to be a factor in picking ease (Kleinhenz, 2003). Future studies combining these three factors may give a more complete picture of ease of picking.

\section{Literature cited}

Kleinhenz, M. 2003. Sweet corn variety trials in Ohio: Recent top performers and suggestions for future evaluations. HortTechnology 13:711-718.

Orzolek, M.D., P.A. Ferretti, W.J. Lamont, K. Demchak, A.A. MacNab, J.M. Halbrendt, S.J. Fleischer, Z. Smilowitz, and W.K. Hock. 2001. Commercial vegetable production recommendations. Penn State Ext. Publ. AGRS-028.

Orzolek, M.D., E. Sánchez, W.J. Lamont, T. Elkner, K. Demchak, G. Lin, J.M. Halbrendt, B.K. Gugino, S.J. Fleischer, L. LaBorde, K. Hoffman, and G.J. San Julian. 2012. Commercial vegetable production recommendations. Penn State Ext. Publ. AGRS-028.
Sánchez, E., T. Butzler, T. Elkner, and L. Stivers. 2012. Pennsylvania statewide cultivar evaluation program. HortScience 47:S323 (abstr.).

Simmone, E. and R. Boozer. 1999. Yield, ear characteristics, and consumer acceptance of selected white sweet corn varieties in the southeastern United States. HortTechnology 9:289-293.

Tracy, W.F. 2001. Sweet corn, p. 162-204. In: A.R. Hallauer (ed.). Specialty corns. 2nd ed. CRC Press, Boca Raton, FL.

U.S. Department of Agriculture. 2014. Agricultural statistics data base, state level data for vegetables and melons, fresh and processed. 5 Sept. 2014. <http://www. agcensus.usda.gov/Publications/2012/ Full_Report/Volume_1,_Chapter_1_ US/usvl.pdf>. 